\title{
Isolation of syringaldehyde from Mikania laevigata medicinal extract and its influence on the fatty acid profile of mice
}

\author{
Ana Paula D. Pedroso, ${ }^{1}$ Sheila C. Santos, ${ }^{1}$ Ana A. Steil, ${ }^{1}$ Francisco Deschamps, ${ }^{2}$ Andersson \\ Barison, ${ }^{3}$ Francinete Campos, ${ }^{3}$ Maique W. Biavatti ${ }^{*}$,
}

${ }^{I}$ Núcleo de Investigações Químico-Farmacêuticas, Universidade do Vale do Itajaí, Caixa Postal 360, 88302-202 Itajai-SC, Brazil,

${ }^{2}$ Estação Experimental de Itajaí, Rod. Antonio Heil, km 6, Caixa Postal 277, 88301-970

Itajai-SC, Brazil,

${ }^{3}$ Laboratório de Ressonância Magnética Nuclear, Departamento de Química, Universidade Federal do Paraná, Caixa Postal 19081, 81531-990 Curitiba-PR, Brazil

\begin{abstract}
RESUMO: "Extrato medicinal de Mikania laevigata: influência no perfil de ácidos graxos em camundongos e isolamento de siringaldeído por CLAE semipreparativa". O gênero Mikania é popularmente conhecido como "guaco" e é utilizado para tratar febre, reumatismo, resfriados e afecções respiratórias. Em trabalho prévio demonstramos sinergismo entre os componentes do extrato de $M$. laevigata para produzir os efeitos farmacológicos esperados, incluindo a cumarina e seu precursor ácido o-cumárico como marcadores. Muitas espécies de Mikania são produtoras de diterpenos ent-caurenos que apresentam atividade antispasmódica e relaxante da musculatura lisa. Buscando a padronização do extrato medicinal de guaco (preparado segundo a farmacopéia brasileira $1^{a}$ edição), este trabalho visou determinar a presença de ácido caurenóico através de CLAE-DAD e isolou siringaldeído através de CLAE semipreparativa, sendo que o primeiro não foi encontrado no extrato e o siringaldeído é um dos seus componentes majoritários. Camundongos isogênicos Balb-C portadores de pneumonite alérgica foram tratados com este extrato, e amostras de pulmão e fígado foram analisadas por CG-DIC quanto ao seu conteúdo de ácidos graxos. A quantidade de ácido araquidônico (ARA) e de ácido docosahexaenóico (DHA) encontrada demonstrou que a composição é distinta em ambos tecidos, e apenas a concentração de DHA hepático foi alterado em função do tratamento, o qual não foi encontrado no pulmão. Não foi detectada diferença significativa na produção de ARA. Tanto o extrato aquoso, quanto a cumarina e o ácido $o$-cumárico, estimularam a síntese de DHA no fígado $(p<0.05)$.
\end{abstract}

Unitermos: Mikania laevigata, Asteraceae, ácido caurenóico, siringaldeído, ácido araquidônico, ácido docosahexaenóico.

\begin{abstract}
The Mikania genus is widely known as "guaco" and is used to treat fever, rheumatism, flu and respiratory diseases. Our previous work evidenced the synergism among $M$. laevigata extract components to produce desirable effects, and included the coumarin precursor, $o$-coumaric acid as marker. Many Mikania species are producers of ent-kaurene diterpenes which presented antiespasmodic and relaxant activities on smooth muscle. Seeking to standardize the guaco extract, which is registered in the Brazilian Pharmacopoea, this paper deals with the determination of kaurenoic acid through LC-PDA and the isolation through LC of syringaldehyde. Kaurenoic acid was not found in the extract, and syringaldehyde is one of the major compounds of pharmacopoeal extract, together with coumarin and $o$-coumaric acid. Samples from the lung and liver of Balb-C isogenic allergic pneumonitis bearing mice, treated with the same extract, were analyzed through GC-FID, and the fatty acid content was determined and analyzed. The results obtained by measuring the arachidonic acid (ARA) and docosahexaenoic acid (DHA) in the liver and lung of treated animals demonstrated that the fatty acid composition is distinct in both tissues, and that in the liver, only the DHA was altered as a result of the treatments. DHA is absent in the lung and in both organs, no significant difference in ARA production was observed. The aqueous extract, coumarin and $o$-coumaric acid stimulated DHA synthesis in the liver $(p<$ $0.05)$.
\end{abstract}

Keywords: Mikania laevigata, Asteraceae, kaurenoic acid, syringaldehyde, arachidonic acid, docosahexaenoic acid. 


\section{INTRODUCTION}

Asteraceae is one of the largest Angiospermae families with ca 1300 genera distributed in 3 subfamilies and 17 tribes. Eupatorieae includes ca 2400 species and the subtribe Mikaniinae contains only the Mikania genus, a species which is neotropical and widely known as "guaco", and is used to treat fever, rheumatism, flu and respiratory diseases (Agra et al., 2007; Soares et al., 2006; Silva et al., 2006). Less than $10 \%$ of 430 species of Mikania has been investigated (Nunez et al., 2004). With morphology, organoleptic characteristics and analogous medicinal uses, $M$. glomerata and M. laevigata are the most widely studied. The main difference between them is the blooming season, which occurs in July for $M$. glomerata and in September for M. laevigata. Also, the leaves of M. laevigata tend to present more prominent lobes than those of M. glomerata (Moraes, 1997). M. glomerata grows in Brazil, Argentina, Paraguay and Uruguay and M. laevigata grows closer to the coast, from São Paulo to Rio Grande do Sul, and is also commonly cultivated.

Many authors attribute the pharmacological effect of "guaco" to the coumarin (1,2-benzopyrone), but is also clear from the pharmacological experiments that this is not the only bioactive component of the tested extracts (Aboy et al., 2002, Leite et al., 1993, Fierro et al., 1999, Soares de Moura et al., 2002, Suyenaga et al., 2002). Our previous work on experimental allergic pneumonitis also demonstrated a synergism among "guaco" medicinal extract components to produce the desirable pharmacological effect, and also included the coumarin precursor, $o$-coumaric acid, as marker (Santos et al., 2006).

Many Mikania species are producers of entkaurene diterpenes: $M$. lindbergii, $M$. laevigata, $M$. oblongifolia, M, sessilifolia (Fabbri et al., 1997), M. glomerata (Veneziani and Oliveira, 1999; Taleb-Contini et al., 2006), M. hirsutissima (Ohkoshi et al., 2004), $M$. hookeriana (Reis et al., 2003), M. banisteriae (Lobitz et al., 1997), M. stipulata (Nascimento and Oliveira, 2001). M. officinallis, M. luetzelburgii, M. belemii and M. malacolepsis (Rodrigues et al., 1996). Kaurane diterpenes presented antiespasmodic and relaxant activities on smooth muscle. Kaurenoic acid (entkaur-16-en-19-oic acid) and its derivatives are potent uterine muscle relaxants, through $\beta_{2}$ adrenergic receptor independent mechanisms, probably antagonist of the calcium channel (Tirapelli et al., 2004). In vitro, PMN and lymphocyte proliferative activities are reported (Ohkoshi et al., 2004), as well as antimicrobial and antifungal activity (Yatsuda et al., 2005, Kuiate et al., 2006), and non-specific cytotoxicity (Costa-Lotufo et al., 2002). Kaurenoic acid is considered a universal marker of Copaiba oil, but could not be found in every harvest (Biavatti et al., 2006).

Coumarin and kaurenoic acid were analyzed together, through capillary gas chromatography in $M$. glomerata, extracted exhaustively with hexane (Vilegas et al., 1997) and also through exhaustive maceration in ethanol-water (7:3), these being the main compounds (Yatsuda et al., 2005).

Bronchial asthma, defined as a chronic inflammatory pathology, affects about $10 \%$ of the population in developed countries. This complex disease is characterized by recurrent episodes of several symptoms such as breathlessness, wheezing, tightness of the chest, obstruction of the airways obstruction and coughing. Essential alterations of asthma are bronchospasm (hyperreactivity), oedema and mucous hypersecretion (bronchial obstruction). Many cell types, including inflammatory cells ( $\mathrm{T}$ lymphocytes, eosinophils, and activated mast cells) and structural cells (epithelial cells, smooth muscle cells, endothelial cells) play a key role in this disease. These few cells release more than 50 different inflammatory mediators responsible for the clinical and pathologic events in asthma. Among these mediators, autacoids, histamine, bradykinine and lipid-derived mediators such as prostaglandins (D2, F2 $\alpha$, I2), TXA2 and cysteinyl leukotrienes (C4, D4, E4), contribute powerfully to the regulation of the airflow by constricting bronchial smooth muscles, increasing mucous secretion and microvascular leakage, and acting as chemoattractant factors for inflammatory cells. It is well accepted that arachidonic acid metabolites (prostanoids and isoprostanes) play a key role in the pathophysiology of diseases associated with inflammation, platelet aggregation and vasoconstriction/relaxation. Consequently, the inhibition of their production and/or the blockade of their respective receptors have greatly contributed to the understanding of their mode of action and their involvement in the pathology, and have also demonstrated clinical effectiveness in bronchial asthmas (Rolin et al., 2006).

Linolenic acid (Omega-3) is the precursor for the long chain polyunsaturated fatty acid docosahexaenoic (DHA) and linoleic (Omega-6) acid is the precursor of arachidonic acid (ARA). Omega-3 plays a protective role in the development of inflammatory and cardiovascular diseases, by competitively inhibiting the biosynthesis of leucotrienes and other pro-inflammatory eicosanoids (Wong, 2005).

Seeking to standardize guaco extract, which is officially registered in the Brazilian Pharmacopoea I (Brandão et al., 2006), this paper deals with the determination of kaurenoic acid through LC-PDA and the isolation through semi-preparative LC of syringaldehyde. Samples from lung and liver of Balb-C isogenic allergic pneumonitis bearing mice, treated with the same extract, were analyzed through GC-FID, and the fatty acid content was determined and analyzed, leading to some conclusions about the mechanism of action of "guaco" in asthma. 


\section{MATERIAL AND METHODS}

\section{Plant material}

Leaves of cultivated specimens obtained from vegetative propagation of authentic M. laevigata Sch ex Baker (identified by Pedro M. Magalhães, Universidade Estadual de Campinas, Campinas, São Paulo, Brazil) were collected in Itajaí (Santa Catarina, Brazil). Voucher specimens of M. laevigata are deposited at the Herbarium Barbosa Rodrigues [HBR Biavatti 30 (30/08/01)] Itajaí, Santa Catarina, Brazil

\section{Extract and samples}

The leaves were air dried $\left(40^{\circ} \mathrm{C}\right.$, forced ventilation), powdered and sieved. Only particles between $0.85-1.4 \mathrm{~mm}$ were used to prepare the extracts. Hydroalcoholic extracts were prepared by percolation with ethanol-water 1:2(v/v) and concentrated to obtain a 1:2 (w/v) extract. For the LC analytical injections of the hydroalcoholic extract, the extract was diluted in ultra pure water 1:5.

For the semi preparative injections, the hydroalcoholic extract was reduced to $1: 1(\mathrm{w} / \mathrm{v})$ in a rotary evaporator, then partitioned with $n$-butanol, and injections of $2.5 \mathrm{mg}$ were performed. A lyophilized aqueous extract ( $1 \%$, prepared by infusion of the leaves) was used to in vivo tests.

\section{LC analysis}

The HPLC system consisted of a Waters 600 pump and 2996 PDA detector, a manual injector Rheodyne 7725i, in line Degasser $\mathrm{AF}$ and software Millenium Empower. The analytical injections (loop 20 $\mu \mathrm{L})$ were carried out on a RPC18 Nova-Pak Waters (150 $\mathrm{x} 3.9 \mathrm{~mm}, 4 \mu \mathrm{M}$ ), and the semi preparative injections (loop $500 \mu \mathrm{L}$ ) on a RPC18 Nova-Pak Waters (300 x $7.8 \mathrm{~mm}, 6 \mu \mathrm{M})$. The mobile phase for the analytical conditions was $\mathrm{MeOH}-\mathrm{H}_{2} \mathrm{O} 0.01 \%$ acetic acid (30:70 $\mathrm{v} / \mathrm{v}$ ), flow rate $1.5 \mathrm{~mL} / \mathrm{min}$, the analysis was monitored at $200 \mathrm{~nm}$, and the column oven fit to $30^{\circ} \mathrm{C}$. The mobile phase for the semi-preparative analysis was $\mathrm{MeOH} 2 \%$ formic acid- $\mathrm{H}_{2} \mathrm{O} 2 \%$ formic acid $(30: 70 \mathrm{v} / \mathrm{v})$, flow rate 6 $\mathrm{mL} / \mathrm{min}$, the analysis was monitored at $225 \mathrm{~nm}$, and the column oven fit to $30^{\circ} \mathrm{C}$.

All the solvents were HPLC grade, and were degassed using an ultrasonic bath before use. The water was purified using a Milli-Q system (Millipore). All the solutions were filtered through $0.45 \mu \mathrm{M}$ membranes (Schleicher \& Schuell, Germany).

The kaurenoic acid was kindly supplied by Ângela Malheiros, UNIVALI.

\section{NMR analysis}

A Bruker AVANCE DRX 400 was used to record mono and bidimensional spectra.

Syringaldehyde or 4-hydroxy-3,5-dimethoxybenzaldehyde: ${ }^{1} \mathrm{H} \mathrm{NMR}\left(400 \mathrm{MHz}, \mathrm{CDCl}_{3}, \mathrm{TMS}\right) \delta 9.83$ $s(1 \mathrm{H}), 7.16 s(2 \mathrm{H})$ and $3.98 s(6 \mathrm{H}) .{ }^{13} \mathrm{C} \mathrm{NMR}(100 \mathrm{MHz}$, $\left.\mathrm{CDCl}_{3}, \mathrm{TMS}\right) \delta 190.6,147.5,141.1,128.6$ and 106.9.

\section{Pharmacological analysis}

To determine the influence of $M$. laevigata aqueous and hydroalcoholic extracts, coumarin and $o$-coumaric acid on the fatty acid profile of mice, a previously developed model of allergic pneumonitis was used (Landgraf et al., 2004).

\section{Animals}

Male BALB/c mice weighing 28-32 g, 6-8 weeks old, from our own animal facilities, were housed in a room with a $12 \mathrm{~h}$ light-dark cycle $\left(19-25^{\circ} \mathrm{C}\right)$ and water and food ad libitum. Animal care and research protocols were used, in accordance with the principles and guidelines adopted by the Brazilian College of Animal Experimentation (COBEA) and approved by the Committee for Animal Research (UNIVALI).

\section{Induction of the allergic pneumonitis}

The mice were sensitized on days 0 and 7 , by intraperitoneal injection of a mixture containing $50 \mu \mathrm{g}$ of ovalbumin and $1 \mathrm{mg}$ of $\mathrm{Al}_{2} \mathrm{O}_{3}$ in saline (a total volume of $0.6 \mathrm{~mL}$ ). At 14 and 21 days after the first immunization, the animals were challenged by exposure to an ovalbumin aerosol (50:50 grade II and III, Sigma) generated by a nebulizer (INALAR, SC, Brazil) delivering particles of $0.5-10 \mu \mathrm{M}$ in diameter at approximately $0.75 \mathrm{cc} /$ $\min$ for $20 \mathrm{~min}$. The concentration of ovalbumin in the nebulizer was $2.5 \% \mathrm{w} / \mathrm{v}$. The control group consisted of animals immunized as described and challenged with saline solution.

\section{Treatments}

By gavages, the animals received the following treatment once a day (twice a day on days 14, 15 and 16) for 21 consecutive days: Group $1(\mathrm{n}=$ 7): negative control (saline). Group $2(n=6)$ : positive control (saline). Group $3(\mathrm{n}=8)$ : aqueous lyophilized extract of M. laevigata $(63.92 \mathrm{~g} / \mathrm{kg})$. Group $4(\mathrm{n}=8)$ : hydroalcoholic extract $1: 2$ of $M$. laevigata $(35.9 \mu \mathrm{g} /$ $\mathrm{kg})$. Group $5(\mathrm{n}=8)$ : $o$-coumaric acid $(0.42 \mathrm{mg} / \mathrm{kg})$. Group $6(\mathrm{n}=9)$ : coumarin $(1.10 \mathrm{mg} / \mathrm{kg})$. Group $7(\mathrm{n}=$ $6)$ : coumarin $+o$-coumaric $(1.52 \mathrm{mg} / \mathrm{kg})$. Doses were selected according to the traditional doses of extracts popularly indicated, and extrapolated to the amount of markers in the extracts (Santos et al., 2006).

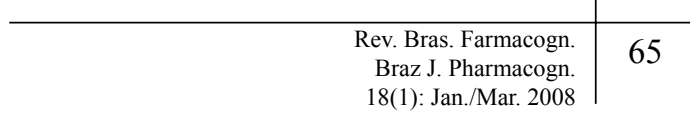



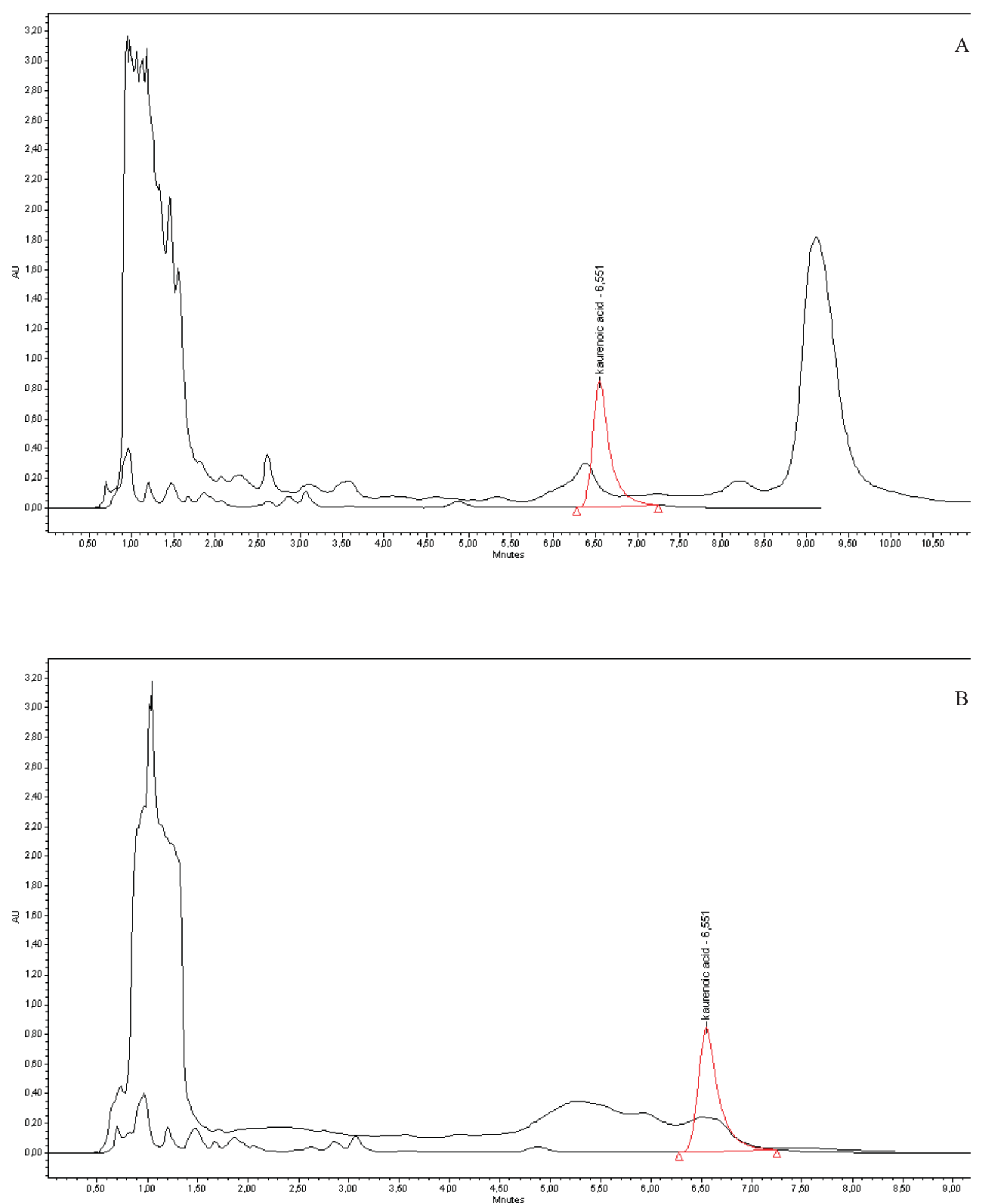

Figure 1. A - Hydroalcoholic extract of M. laevigata and kaurenoic acid (standard). B - Diclorometane extract of M. laevigata and kaurenoic acid (standard). For chromatographic conditions, see experimental. 


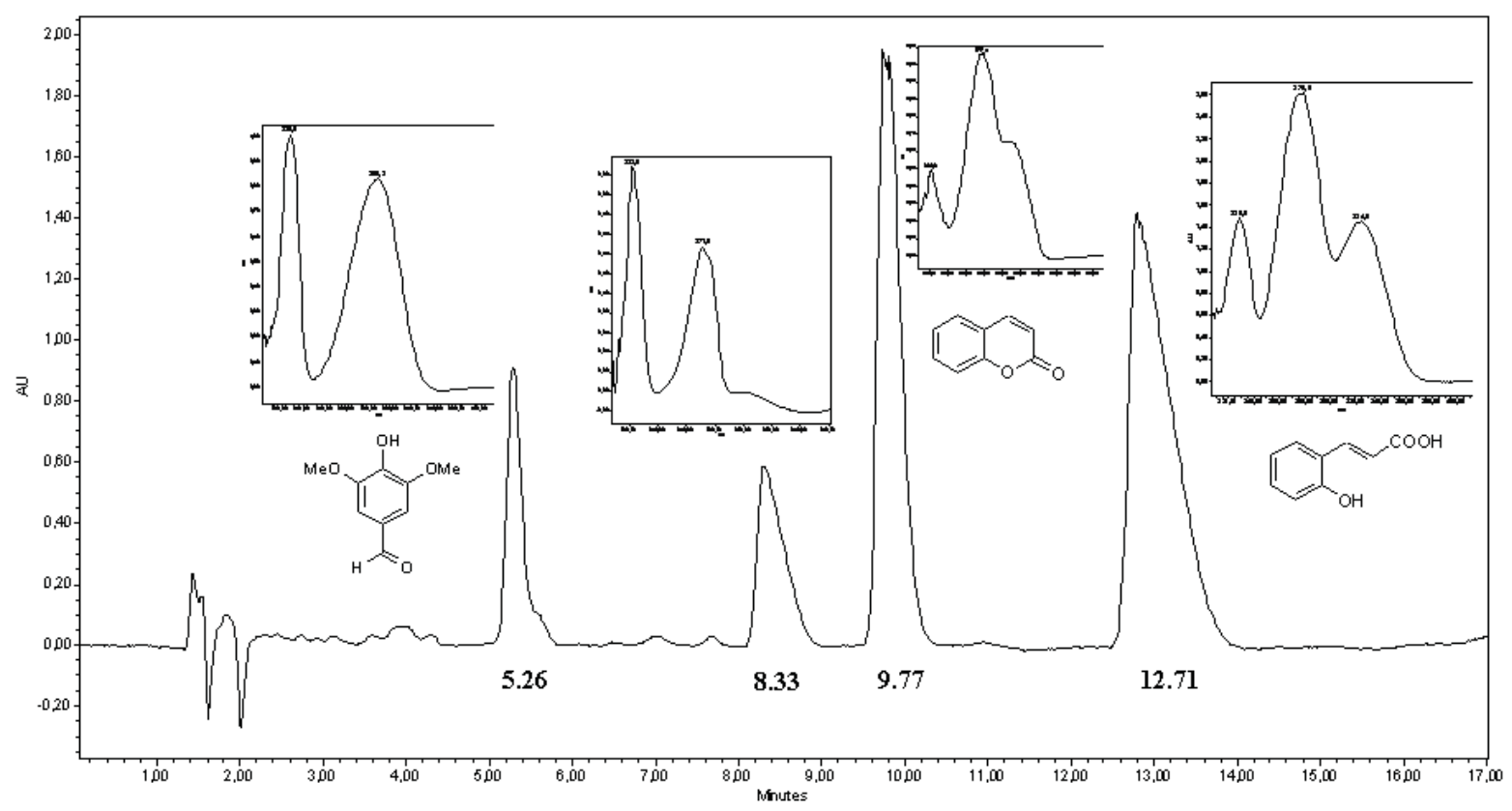

Figure 2. Semi-preparative analysis of guaco medicinal extract. For chromatographic conditions, see experimental.

Table 1. Influence of the treatments (aqueous, hydroalcoholic extracts and markers) on the fatty acid profile in mice lung and liver. Mean followed by different letters differ from the Duncan test by $5 \%$ of error probability.

\begin{tabular}{clcccccccc}
\hline \multirow{2}{*}{ Tissue } & Treatment & Palmitic & Estearic & Saturated & Oleic & Linoleic & ARA & DHA & Unsaturated \\
\hline \multirow{2}{*}{ Lung } & Negative Control & 32.92 & $15.20^{\mathrm{d}}$ & 32.92 & $24.46^{\mathrm{a}}$ & $20.55^{\mathrm{a}}$ & 5.92 &. & 5.92 \\
& Positive Control & 34.40 & $24.04^{\mathrm{bc}}$ & 34.40 & $18.49^{\mathrm{bc}}$ & $14.90^{\mathrm{b}}$ & 8.16 &. & 8.16 \\
& Aqueous extract & 34.20 & $35.96^{\mathrm{a}}$ & 34.20 & $12.86^{\mathrm{d}}$ & $9.82^{\mathrm{d}}$ & 7.14 &. & 7.14 \\
& Hydroalcoholic ext & 34.38 & $27.48^{\mathrm{b}}$ & 34.38 & $17.36^{\mathrm{c}}$ & $13.08^{\mathrm{cd}}$ & 7.69 &. & 7.69 \\
& O-coumaric acid & 34.04 & $20.20^{\mathrm{c}}$ & 34.04 & $21.56^{\mathrm{ab}}$ & $17.82^{\mathrm{ab}}$ & 6.37 &. & 6.37 \\
& Coumarin & 33.33 & $29.98^{\mathrm{b}}$ & 33.33 & $15.39^{\mathrm{cd}}$ & $13.51^{\mathrm{c}}$ & 7.76 &. & 7.76 \\
& Coumarin + acid & 33.28 & $28.87^{\mathrm{b}}$ & 33.28 & $17.13^{\mathrm{c}}$ & $13.25^{\mathrm{cd}}$ & 7.45 &. & 7.45 \\
Liver & Negative Control & 26.33 & 20.57 & 46.89 & 10.92 & 18.60 & 15.53 & $8.05^{\mathrm{ab}}$ & 45.05 \\
& Positive Control & 26.61 & 20.75 & 47.37 & 11.90 & 19.19 & 14.55 & $6.99^{\mathrm{b}}$ & 45.64 \\
& Aqueous extract & 26.23 & 20.01 & 46.24 & 10.15 & 18.81 & 16.23 & $8.56^{\mathrm{a}}$ & 45.19 \\
& Hydroalcoholic ext & 26.05 & 19.57 & 45.62 & 11.15 & 19.47 & 15.72 & $8.04^{\mathrm{ab}}$ & 46.34 \\
& O-coumaric acid & 26.01 & 21.15 & 47.16 & 9.45 & 18.12 & 16.98 & $8.28^{\mathrm{a}}$ & 44.55 \\
& Coumarin & 25.41 & 19.68 & 45.10 & 9.64 & 18.75 & 17.60 & $8.91^{\mathrm{a}}$ & 45.99 \\
Coumarin+ acid & 26.20 & 22.94 & 49.14 & 9.40 & 17.02 & 16.45 & $7.98^{\text {ab }}$ & 42.87 \\
\hline
\end{tabular}

\section{Biochemical analysis}

The right lung (200 $\mathrm{mg})$ and liver $(300 \mathrm{mg})$ were removed and the total lipids were extracted using the Bligh and Dyer (1959) method. To determine the fatty acids in the lipids, they were converted to methyl esters by adding $\mathrm{KOH} 0.1 \mathrm{M}$ in $\mathrm{MeOH}$ and kept at 60 ${ }^{\circ} \mathrm{C} / 1 \mathrm{~h}$. After cooling, $\mathrm{H}_{2} \mathrm{SO}_{4} 1 \mathrm{M}$ in $\mathrm{MeOH}$ was added and it was warmed again to $60{ }^{\circ} \mathrm{C} / 1 \mathrm{~h}$, cooled, and extract with $n$-hexane and filtered samples injected (1 $\mu \mathrm{L}$ ) on GC-FID, using a Shimadzu GC-17A, equipped with automatic injector AOC20I. Helium was used as the carrier gas $(17 \mathrm{~mL} / \mathrm{min})$, and nitrogen, hydrogen and synthetic air with 30,30 and $300 \mathrm{~mL} / \mathrm{min}$. The temperature program was an isotherm $140{ }^{\circ} \mathrm{C}(5 \mathrm{~min})$ followed by $4{ }^{\circ} \mathrm{C} / \mathrm{min}$ until $240^{\circ} \mathrm{C}$, kept $10 \mathrm{~min}$. Injector 
and detector temperatures were $240{ }^{\circ} \mathrm{C}$ and $260{ }^{\circ} \mathrm{C}$, respectively, and the capillary column used was SP2340 $[100 \%$ poly (bis-cyanopropyl-siloxane) $-60 \mathrm{~m} \times 0.25$ mm id x $0.2 \mu \mathrm{M}$ ], from Supelco.

The fatty acids were identified by comparing the retention time with the standards (Supelco 37 Components FAME Mix) and the percent of every component in the sample was determined in relation to the total area of identified peaks.

\section{Statistical analysis}

The Duncan's statistical test $(p<0.05)$ was used to contrast the averages of the treatments.

\section{RESULTS AND DISCUSSION}

The chromatographic profile of the hydroalcoholic extract 1:2 can be seen in Figure 1A. Compared with the standard kaurenoic acid, any corresponding peak can be recognized in the extract, by the detector employed. The PDA detector is not effective for detecting compounds presenting few cromophores. To check whether the absence of kaurenoic acid was due to the extraction procedure, an extract with dichloromethane was prepared and injected under the same conditions (Figure 1B). Any free kaurenoic acid is present in the medicinal extract of "guaco". This diterpene and others are reported as antimicrobial, but Barbosa et al. (1994) using a "guaco" extract produced using the same method, did not find any antimicrobial activity. On the other hand, hexane fraction (with kaurenoic acid as a major compound) of ethanol extract of $M$. laevigata and $M$. glomerata, were active against Streptococcus mutans (Yatsuda et al., 2005). The glycosilated form of kaurenoic acid was found in other species of Mikania (Ohkoshi et al., 2004).

From the semipreparative analysis of the $n$-butanol fraction of the medicinal extract, four welldefined peaks were found (F1-F4, Figure 2). The two last correspond to coumarin and $o$-coumaric acid. The two first peaks present a phenol profile, F1 being identified as syringaldehyde through NMR mono and bidimensional analysis and also by direct comparison with the respective literature data (SBDS database). The F2 peak was not identified, but according to the UV spectrum, a furofurane lignan derivative can be expected (Cuenca et al., 1991).

As a general rule, syringaldehyde and vanillin are the predominant compounds in aged alcoholic beverages due to the lignin hydrolysis, which is the major chemical process that occurs during aging in wooden barrels. This is the process from which several phenolic compounds are extracted and affect the final organoleptic characteristic of the beverage (Aquino et al., 2006). Is not commonly isolated from the leaves, and is isolated from Mikania (Sharp et al., 2001) for the first time here. Little research has been conducted in order to verify its bioactivity, and only weak antioxidant activity has previously been found (Bortolomeazzi et al., 2007).

The results obtained by measuring the ARA and DHA in the liver and lung of treated animals demonstrated that the fatty acid composition is distinct in both tissues, while in the liver, only the DHA was altered as a result of the treatments. DHA is absent in the lung and in both organs, no significant difference in ARA production was observed (Table 1). The aqueous extract, coumarin and $o$-coumaric acid stimulated DHA synthesis in the liver $(p<0.05)$. The presence of inflammation enhanced the stearic acid concentration in the lungs, perhaps to reinforce the energy supply in the cells or to stabilize the membranes due to the increased temperature, or to reduce the unsaturated proportion to decrease the possibility of oxidation due to the enhanced oxidation in the lung environment. It seems that effects of the coumarin are prevalent in comparison with the $o$-coumaric acid, since it did not alter the fatty acid profile.

\section{REFERENCES}

Aboy AL, Ortega GG, Petrovick PR, Langeloh A, Bassani VL 2002. Atividade antiespasmódica de soluções extrativas de folhas de Mikania glomerata Sprengel (guaco). Acta Farm Bonaerense 21: 185-191.

Agra MF, França PF, Barbosa-Filho JM 2007. Synopsis of the plants known as medicinal and poisonous in Northeast of Brazil. Rev Bras Farmacogn 17: 114-140.

Aquino FWB, Rodrigues S, Nascimento RF, Casimiro ARS 2006. Simultaneous determination of aging markers in sugar cane spirits. Food Chem 98: 569-574.

Barbosa AD, Ferreira RC, Valente PHM 1994. Atividade antimicrobiana de extratos fluidos de plantas medicinais brasileiras. LECTA - USF 12: 153-163.

Biavatti MW, Dossin D, Deschamps FC, Lima MP 2006. Análise de óleos-resinas de copaíba: contribuição para o seu controle de qualidade. Rev Bras Farmacogn 16: $230-235$.

Bligh ED, Dyer WJ 1959. A rapid method of total lipid extraction and purification. Can J Biochem Physiol 37: 911-917.

Bortolomeazzi R, Sebastianutto N, Toniolo R, Pizzariello A 2007. Comparative evaluation of the antioxidant capacity of smoke flavouring phenols by crocin bleaching inhibition, DPPH radical scavenging and oxidation potential. Food Chem 100: 1481-1489.

Brandão MGL, Cosenza GP, Moreira RA, Monte-Mor RLM 2006. Medicinal plants and other botanical products from the Brazilian Official Pharmacopoeia. Rev Bras Farmacogn 16: 408-420.

Costa-Lotufo V, Cunha GMA, Farias PAM, Viana GSB, Cunha KMA, Pessoa C, Moraes MO, Silveira ER, Gramosa NV, Rao VSN 2002. The cytotoxic and embryotoxic effects of kaurenoic acid, a diterpene isolated from Copaifera langsdorffii oleo-resin. Toxicon 40: 1231-1234. 
Cuenca MDR, Catalan CAN, Diaz JG, Herz W 1991. Monoterpenes and lignans from Mikania saltensis. $J$ Nat Prod 54: 1162-1164.

Fabbri H, de Oliveira DC, Vichnewski W, Herz W 1997. Diterpenes of Mikania lindbergii Baker. Biochem Syst Ecol 25: 563-564.

Fierro IO, Silva AC, Lopes CS, Soares de Moura R, BarjaFidalgo C 1999. Studies on the anti-allergic activity of Mikania glomerata. J Ethnopharmacol 66: 19-24.

Kuiate JR, Bessière JM, Zollo PHA, Kuate SP 2006. Chemical composition and antidermatophytic properties of volatile fractions of hexanic extract from leaves of Cupressus lusitanica Mill. from Cameroon. $J$ Ethnopharmacol 103: 160-165.

Landraf RG, Steil AA, Sirois P, Jancar S 2004. Inflamm Res 53: 78-83.

Leite MGR, Souza CL, Silva MAM, Moreira LKA, Matos FJA, Viana GSB 1993. Estudo farmacológico comparativo de Mikania glomerata Spreng (guaco), Justicia pectoralis Jacq (anador) e Torresea cearensis Fr. All (cumarú). Rev Bras Farm 74: 12-15.

Lobitz GO, Tamayo-Castillo G, Merfort I 1997. Diterpenes and sesquiterpenes from Mikania banisteriae. Phytochemistry 46: 161-164.

Moraes MDA 1997. Família Asteraceae na Planicie Litorânea de Picinguaba - Município de Ubatuba, Campinas. Tese de Doutorado - Instituto de Biologia - Universidade Estadual de Campinas, São Paulo.

Nascimento AM, Oliveira DCR 2001. Kaurene diterpenes and other chemical constituents from Mikania stipulacea (M. Vahl) Willd. J Braz Chem Soc 12: 552-555.

Nunez CV, Amendola MC, Lago JHG, Roque NF 2004. Diterpene acids from Mikania sp. nov (Asteraceae). Biochem Syst Ecol 32: 233-237.

Ohkoshi E, Kamo S, Makino M, Fujimoto Y 2004. entKaurenoic acids from Mikania hirsutissima (Compositae). Phytochemistry 65: 885-890.

Reis AA, Mendes CC, Ferraz TPL, Roque NF 2003. Terpenes from Mikania hookeriana. Biochem Syst Ecol 31: 1061-1062.

Rodrigues RFO, Alvarenga MA, Kato ETM 1996. Constituintes químicos de Mikania macrolepsis Robinson. LECTA - USF 14: 29-47.

Rolin S, Masereel B, Dogné JM 2006. Prostanoids as pharmacological targets in COPD and asthma. Eur $J$ Pharmacol 533: 89-100.

Santos SC, Krueger CL, Steil AA, Kreuger MR, Biavatti MW, Wisniewki Jr A 2006. LC characterization of guaco medicinal extracts: Mikania laevigata and $M$. glomerata, and its effects on allergic pneumonitis. Planta Med 72: 679-684.

Sharp H, LatifZ, Bartholomew B, Thomas D, Thomas B, Sarker SD, Nash RJ 2001. Emodin and syringaldehyde from Rhamnus pubescens (Rhamnaceae). Biochem Syst Ecol 29: 113-115.

Silva MIG, Gondim APS, Nunes IFS, Sousa FCF 2006. Utilização de fitoterápicos nas unidades básicas de atenção à saúde da família no município de Maracanaú (CE). Rev Bras Farmacogn 16: 455-462.

Soares de Moura R, Costa SS, Jansen JM, Silva CA, Lopes CS, Bernardo-Filho M, Nascimento da Silva V, Criddle DN, Nunes Portela B, Rubenich LMS, Gagliardi Araújo R, Carvalho LCRM 2002. Bronchodilator activity of Mikania glomerata Sprengel on human bronchi and guinea-pig traquea. J Pharm Pharmacol 54: 249-256.

Soares AKA, Carmo GC, Quental DP, Nascimento DF, Bezerra FAF, Moraes MO, Moraes MEA 2006. Avaliação da segurança clínica de um fitoterápico contendo Mikania glomerata, Grindelia robusta, Copaifera officinalis, Myroxylon toluifera, Nasturtium officinale, própolis e mel em voluntários saudáveis. Rev Bras Farmacogn 16: 447-454.

Suyenaga ES, Reche E, Farias FM, Schapoval EES, Chaves CGM, Henriques AT 2002. Antiinflammatory investigation of some species of Mikania. Phytother Res 16: 514-518.

Taleb-Contini SH, Santos PA, Rodrigo CS, Veneziani RCS, Pereira AMS, França SC, Lopes NP, Oliveira DCR 2006. Differences in secondary metabolites from leaf extracts of Mikania glomerata Sprengel obtained by micropropagation and cuttings. Rev Bras Farmacogn 16: 596-598.

Tirapelli CR, Ambrosio SR, da Costa FB, Coutinho ST, de Oliveira DCR, de Oliveira AM 2004. Analysis of the mechanisms underlying the vasorelaxant action of kaurenoic acid in the isolated rat aorta. Eur $J$ Pharmacol 492: 233-241.

Veneziani RCS, de Oliveira DCR 1999. Constituents of Mikania glomerata Sprengel. Biochem Syst Ecol 27: 99-102.

Vilegas JHY, de Marchi E, Lanças FM 1997. Determination of coumarin and kaurenoic acid in Mikania glomerata (guaco) leaves by capillary gas chromatography. Phytochem Analysis 8: 74-77.

Wong KW 2005. Clinical efficacy of n-3 fatty acid supplementation in patients with asthma. $J$ Am Diet Assoc 105: 98-105.

Yatsuda R, Rosalen PL, Cury JA, Murata RM, Rehder VLG, Melo LV, Koo H 2005. Effects of Mikania genus plants on growth and cell adherence of mutans streptococci J Ethnopharmacol 97: 183-189. 